\title{
Report on the Probable Ages of Young Fish collected by Mr. Holt in the North Sea.
}

\author{
By
}

\section{J. T. Cunningham, M.A.}

During the past summer Mr. Holt has sent me from time to time young specimens of fish which he has collected, in order that I might report upon the evidence which they afforded as to the rate of growth of the various species in the North Sea. He has also supplied me with a complete list containing the names and the measurements of all the specimens he has collected, including many others besides those sent to me. I have simply studied the specimens and the list, and endeavoured to estimate the probable ages of the specimens. The necessary information as to the limits and duration of the spawning period in the case of each species has also been supplied to me by Mr. Holt. I have registered below the observed specimens of each species separately in the chronological order of their capture. All have been collected in the course of the current year.

The principal sources whence these specimens were obtained were the shrimp nets worked on the sands at Cleethorpes, the shrimptrawls in the Humber, Grimsby Market, and the deep sea trawling grounds. The shrimp-nets are of two kinds-the shove-net worked by hand, the fisherman wading in the water ; and the cart-trawl,* which is drawn by a horse. The shove-net is ten feet wide at the lower end, the cart-trawl is larger. In Mr. Holt's list there are records of fish taken in these nets at the end of April, in May, in June, in July, and in September. The fish obtained from them were most numerous at the end of April, when they consisted of hundreds of small plaice, with a few flounders, dabs, soles, turbots, brill, and smelt. With these were numerous valueless fish, such as gobies and dragonets, which need not here be considered. The majority of the small plaice were $1 \frac{1}{2}$ to 3 inches long, and I think there is little doubt that they were derived from the same year's spawning, which commenced in January. None of the other

* Locally termed a "shrimp-seine" (vide p. 387). 
valuable fish from these nets in April were so young, all being in their second year at least. In May the same kinds of fish were obtained, but the plaice were not so numerous; in addition to those mentioned, two whiting occurred, about eleven months old, 4 and $5 \frac{1}{2}$ inches long. In June also plaice of the year occurred in large numbers, over 200 on the $3 \mathrm{rd}$ in the cart-trawl. A few soles, flounders, plaice, turbot, brill, one year old, continued to be taken. In July the year's plaice are in much smaller numbers, 25 on one occasion, 13 on another. Soles and brill 3 to 7 inches long still occurred. On September 10th plaice of the year were still present, but in small numbers, only 40 under 3 inches being taken; on this date one whiting $3 \frac{3}{4}$ inches long, and hatched the preceding spring, was taken.

If we turn next to the fish taken by the fish- and shrimp-trawls in the Humber at a depth of 1 to 2 fathoms, we find in March plaice 5 to 9 inches long the most numerous; the majority of these are one year old, some may be two years; there are also a few year-old dabs, $1 \frac{1}{4}$ to $3 \frac{1}{4}$ inches; a year-old sole, $5 \frac{3}{4}$ inches, and five specimens of year-old whiting, $4 \frac{3}{4}$ to 6 inches. In May a considerable number of soles 7 to 10 inches long were taken, some of these are only one year old, but many of the larger are probably two years. There are also a large number of flounders 5 to 10 inches, and some larger, and plaice of the same sizes. Most of the flounders are two years old and upwards, and many of them adult and mature. The greater number of the plaice are 7 to 8 inches long, and these are probably only one year old. In June a large number of soles occur, of various sizes, from 7 to 12 inches; the smaller of these may be only one year old, the majority are two years, and some are probably adult. In July there occur only a few soles on one occasion, 5 to 7 inches long, one year old. In August there are no observations. September is remarkable for the appearance of large numbers of whiting $2 \frac{1}{2}$ to 5 inches long, and evidently derived from eggs shed in the preceding spring ; 254 were taken on the 9 th ; cod of similar size occur, but in much smaller numbers. On the 9 th half a dozen of the year's plaice were also taken.

These observations give a distinct and accurate idea of the destruction of young fish by shrimp fishing at the mouth of the Humber. The young fry of the year are largely taken in the case of two species only, the plaice and the whiting, the former at the very edge of the water by the shove-net and cart-trawl, the latter by the shrimp-trawl. These results, of course, only hold good for the months mentioned, the observations not extending beyond September. A considerable number of year-old, and therefore im- 
mature specimens, are taken of the sole, plaice, turbot, and brill by the shove-nets, and they are also taken mixed with older specimens, some of which are mature, by the shrimp-trawls. Mr. Holt writes to me that spent soles begin to appear in the Humber about the beginning of July, and become numerous afterwards; that before July there are none but immature soles, with the occasional exception of a large fish which has not yet spawned. It must be remembered that, according to my observations in the flounder, only a minority of fish are mature at two years old. It is especially noteworthy that not a single lemon sole (Pleuronectes microcephalus) was taken in the shrimp-nets in the Humber.

The specimens in the list, which were obtained on the deep-sea trawling ground, are few in number. The most interesting are small cod, whiting, and haddock taken in July and August. These are from 2 to 5 inches long, and evidently derived from the year's spawning. The haddock were taken at thirty fathoms on the Great Fisher Bank, and also fifty to sixty miles to the eastward of Spurn Light-vessel at twenty fathoms, but most abundantly on the latter ground where eight occurred on one occasion, thirty-one on another. The young cod were most numerous on the Great Fisher Bank, where whiting did not occur at all; eight of the latter occurred in the other region mentioned. This shows that the whiting fry of the year are not confined to inshore waters, while the haddock fry seem to be absent from the latter entirely.

Of the fish obtained in Grimsby Market the smallest sole was 8 inches long, many were only 9 or 10 inches, but the majority were over 10 inches. Those about 8 inches long may have been only one year old, but the rest were probably two years or more. Plaice from the market were examined in May and June, and large numbers were obtained between 6 and 12 inches in length, those between 8 and 10 inches being most numerous. According to Mr. Holt all these were immature, but a male plaice was observed once to be ripe at $6 \frac{1}{4}$ inches. Some plaice may reach 12 inches in one year, but probably only a small proportion, so that these small plaice from the market may be considered as mixed, some one year and some two years old. The only other fish in the list taken from the market were 140 turbot 11 to 15 inches long. Most of these were probably two years old or more, though some turbot may reach 12 inches in a year. 
Pleuronectes platessa, the Plaice.

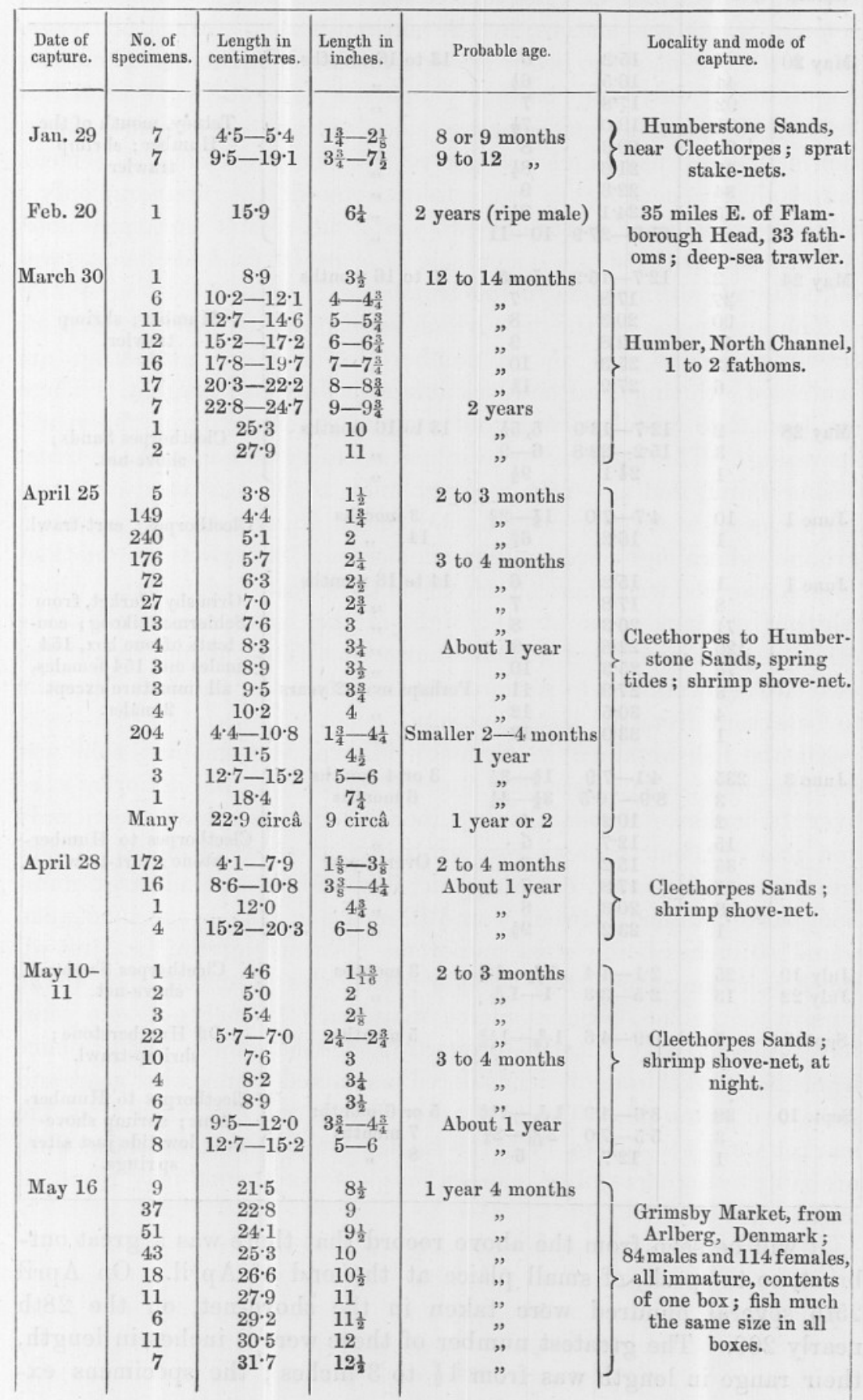




\begin{tabular}{|c|c|c|c|c|c|}
\hline $\begin{array}{l}\text { Date of } \\
\text { capture. }\end{array}$ & $\begin{array}{c}\text { No. of } \\
\text { specimens. }\end{array}$ & $\begin{array}{l}\text { Length in } \\
\text { centimetres. }\end{array}$ & $\begin{array}{l}\text { Length in } \\
\text { inches. }\end{array}$ & Probable age. & $\begin{array}{l}\text { Locality and mode of } \\
\text { capture. }\end{array}$ \\
\hline May 20 & $\begin{array}{r}7 \\
44 \\
92 \\
81 \\
92 \\
52 \\
34 \\
15 \\
8\end{array}$ & \begin{tabular}{|c|}
$15 \cdot 2$ \\
$16 \cdot 5$ \\
$17 \cdot 8$ \\
$19 \cdot 0$ \\
$20 \cdot 3$ \\
$21 \cdot 6$ \\
$22 \cdot 8$ \\
$24 \cdot 1$ \\
$25 \cdot 3-27 \cdot 9$
\end{tabular} & $\begin{array}{l}6 \\
6 \frac{1}{2} \\
7 \\
7 \frac{1}{2} \\
8 \\
8 \frac{1}{2} \\
9 \\
9 \frac{1}{2} \\
10-11\end{array}$ & 13 to 16 months & $\begin{array}{l}\text { Tetney, mouth of the } \\
\text { Humber; shrimp } \\
\text { trawler. }\end{array}$ \\
\hline May 24 & $\begin{array}{r}2 \\
27 \\
90 \\
67 \\
42 \\
6\end{array}$ & \begin{tabular}{|c|}
$12 \cdot 7-15 \cdot 2$ \\
$17 \cdot 8$ \\
$20 \cdot 3$ \\
$22 \cdot 8$ \\
$25 \cdot 3$ \\
$27 \cdot 9$
\end{tabular} & $\begin{array}{c}5-6 \\
7 \\
8 \\
9 \\
10 \\
11\end{array}$ & 13 to 16 months & $\begin{array}{l}\text { Humber; shrimp } \\
\text { trawler. }\end{array}$ \\
\hline May 28 & $\begin{array}{l}2 \\
3 \\
1\end{array}$ & $\begin{array}{c}12 \cdot 7-13 \cdot 9 \\
15 \cdot 2-22 \cdot 8 \\
24 \cdot 1\end{array}$ & $\begin{array}{c}5,5 \frac{1}{2} \\
6-9 \\
9 \frac{1}{2}\end{array}$ & 13 to 16 months & $\begin{array}{l}\text { Cleethorpes Sands; } \\
\text { shove-net. }\end{array}$ \\
\hline June 1 & $\begin{array}{r}10 \\
1\end{array}$ & $\begin{array}{c}4 \cdot 7-7 \cdot 0 \\
16 \cdot 2\end{array}$ & $1 \frac{7}{8}-2 \frac{3}{4}$ & $\begin{array}{l}3 \text { months } \\
14 \quad,\end{array}$ & Cleethorpes; cart-trawl. \\
\hline June 1 & $\begin{array}{r}1 \\
8 \\
71 \\
120 \\
76 \\
5 \\
4 \\
1\end{array}$ & $\begin{array}{l}15 \cdot 2 \\
17 \cdot 8 \\
20 \cdot 3 \\
22 \cdot 8 \\
25 \cdot 3 \\
27 \cdot 9 \\
30 \cdot 5 \\
33 \cdot 0\end{array}$ & $\begin{array}{r}6 \\
7 \\
8 \\
9 \\
10 \\
11 \\
12 \\
13\end{array}$ & $\begin{array}{c}14 \text { to } 18 \text { months } \\
\text { Perhaps over } 2 \text { years } \\
, "\end{array}$ & $\left\{\begin{array}{c}\text { Grimsby Market, from } \\
\text { Schiermonnikoog; con- } \\
\text { tents of one box, } 154 \\
\text { males and } 154 \text { females, } \\
\text { all immature except } \\
2 \text { males. }\end{array}\right.$ \\
\hline June 3 & $\begin{array}{r}235 \\
3 \\
2 \\
15 \\
35 \\
17 \\
8 \\
1\end{array}$ & $\begin{array}{c}4 \cdot 1-7 \cdot 9 \\
8 \cdot 9-10 \cdot 5 \\
10 \cdot 2 \\
12 \cdot 7 \\
15 \cdot 2 \\
17 \cdot 8 \\
20 \cdot 3 \\
23 \cdot 2\end{array}$ & $\begin{array}{l}1 \frac{5}{8}-3 \frac{1}{8} \\
3 \frac{1}{2}-4 \frac{1}{8} \\
4 \\
5 \\
6 \\
7 \\
8 \\
9 \frac{1}{8}\end{array}$ & $\begin{array}{c}3 \text { or } 4 \text { months } \\
6 \text { months } \\
\text { Over } 1 \text { year } \\
\text { ", }\end{array}$ & $\begin{array}{l}\text { Cleethorpes to Humber- } \\
\text { stone; cart-trawl. }\end{array}$ \\
\hline $\begin{array}{l}\text { July } 19 \\
\text { July } 22\end{array}$ & $\begin{array}{l}25 \\
13\end{array}$ & $\begin{array}{l}2 \cdot 1-4 \cdot 4 \\
2 \cdot 5-3 \cdot 3\end{array}$ & $\frac{1 \frac{1}{16}-1 \frac{3}{4}}{1-1 \frac{5}{16}}$ & $\begin{array}{c}3 \text { months } \\
,\end{array}$ & $\begin{array}{l}\text { Cleethorpes Sands; } \\
\text { shove-net. }\end{array}$ \\
\hline Sept. 9 & 5 & $3 \cdot 9-4 \cdot 6$ & $1 \frac{9}{16}-1 \frac{13}{16}$ & 5 months & $\begin{array}{l}\text { Off Humberstone; } \\
\text { shrimp-trawl. }\end{array}$ \\
\hline Sept. 10 & $\begin{array}{r}38 \\
3 \\
1\end{array}$ & $\begin{array}{c}3 \cdot 6-4 \cdot 9 \\
5 \cdot 5-7 \cdot 0 \\
12 \cdot 7\end{array}$ & $\mid \begin{array}{c}1 \frac{7}{16}-1 \frac{15}{16} \\
2 \frac{3}{16}-2 \frac{3}{4}\end{array}$ & $\begin{array}{l}5 \text { or } 6 \text { months } \\
7 \text { months } \\
8\end{array}$ & $\left\{\begin{array}{c}\text { Cleethorpes to Humber- } \\
\text { stone; shrimp shove- } \\
\text { net; low tide just after } \\
\text { springs. }\end{array}\right.$ \\
\hline
\end{tabular}

It will be seen from the above record that there was a great outburst, so to speak, of small plaice at the end of April. On April 25 th several huudred were taken in the shove-net, on the 28th nearly 200. The greatest number of these were 2 inches in length, their range in length was from $1 \frac{1}{2}$ to 3 inches; the specimens ex- 
ceeding 3 inches were comparatively few in number. In May only a few specimens of this size were taken. They appear only on one day (or night), May 10th-11th, the number is less than fifty ; the average size of these is a little larger, the greatest number being from $2 \frac{1}{4}$ to $2 \frac{3}{4}$. At the beginning of June another outburst appears; on the 1st only a few are taken, but on the 3rd 235 are taken in the cart-trawl. In July, in the middle of the month a few still smaller specimens are taken, only about $1 \frac{1}{2}$ inches long, and as late as the beginning of September we find thirty-eight specimens under 2 inches long in the shove-net. Mr. Holt finds that plaice spawn in the North Sea chiefly from the middle of January to the end of March, though a few may spawn earlier or later. I think it is evident that the large number of specimens 2 inches in length taken at the end of April are derived from the eggs shed in January, and are therefore three months old. Those which are larger may be a week or two older or may have grown faster. I have shown in previous papers how variable the rate of growth is. Those which are smaller than 2 inches, may in like manner be younger, or may have grown more slowly. It is difficult to fix the maximum size of specimens derived from the immediately preceding spawning season. I have fixed it at 3 inches, referring specimens above this length to the spawning of the previous year. I do not understand why comparatively few of these young plaice were taken in May. The large number taken at the beginning of June include chiefly those hatched in February and March. Those taken in July and September are few in number, and represent those whose growth has been slow, who have been behindhand in the competition for food, or which are the progeny of the last spawners of the season, of parents which spawned in April or even in May. All these young plaice of the year are taken on the flat sandy shores near Grimsby in shrimp nets, either in the shove-net, which is worked by hand, and has a spread of 10 feet, or by the cart trawl which is towed by a horse. I have shown previously (this Journal, vol. ii, No. 2, p. 99), that plaice of the year occur in June on similar sandy shores near Plymouth. It is evident that the destruction or, at any rate, the capture of plaice fry by shrimpers at the mouth of the Humber must be enormous.

I have considered the seven specimens taken in sprat stake-nets on January 29th to be remnants of the previous year's brood. Possibly some plaice may spawn in December, but even then the young fish produced could not reach a length of two inches in less than two months. These small fish must, therefore, be derived from the spawning of the previous year, and be eight or nine months old at least. The consideration of such specimens as these shows conclu- 
sively that fish may live in the sea for months, with scarcely any increase in size, just as some of the flounders out of a number kept by me in captivity. Some of my captive flounders were only about 2 inches in length when one year old; these plaice taken at Humberstone in January were of the same length, and must have been at least eight months old, while they may have been more.

It is not easy to infer from the data given in the table, the average size or the limits of growth of the plaice in their second year. In the entry for May 20th we have a large number of specimens certainly over a year old, and the greater number of these are $6 \frac{1}{2}$ to $8 \frac{1}{2}$ inches long. The flounders I reared in captivity were mostly from 4 to 6 inches long at one year of age, and as the plaice in the North Sea is a much larger fish, and these were taken some months after the principal spawning season, these specimens may all have been in their second year only. But on the other hand, it is certain that some fish at two years old are not bigger than others at one year, so that it is impossible to say whether some fish in their third year may not be present in this lot.

The maximum growth for a plaice of fourteen to sixteen months old is difficult to fix with the evidence at present available. The maximum observed by me in the flounder at one year was $7 \frac{1}{2}$ inches, and as the plaice in the North Sea reaches 28 inches in length, while the flounder's maximum length is 16 or 17 inches, individual plaice might reach $12 \frac{1}{2}$ inches in sixteen months. I have accordingly estimated the age of the specimens of May 16th from the Denmark coast at twelve to sixteen months; a conclusion supported by the fact that they were all immature. But some of these specimens may be in their third year.

It will be seen from the entry of March 30th, of fish taken in the Humber by a shrimp trawler, that many plaice occur, only 4,5 , or 6 inches long, which are certainly a year old.

Pleuronectes flesus, the Flounder.

\begin{tabular}{|c|c|c|c|c|c|}
\hline $\begin{array}{l}\text { Date of } \\
\text { capture. }\end{array}$ & $\begin{array}{l}\text { No. of } \\
\text { specimens. }\end{array}$ & $\begin{array}{l}\text { Length in } \\
\text { centimetres. }\end{array}$ & $\begin{array}{l}\text { Length in } \\
\text { inches. }\end{array}$ & Probable age. & Locality and mode of capture. \\
\hline April 25 & $\begin{array}{c}3 \\
3 \\
1 \\
\text { Several }\end{array}$ & $\begin{array}{c}6 \cdot 3-8 \cdot 4 \\
11 \cdot 4-12 \cdot 4 \\
23 \cdot 5 \\
\text { About } 22 \cdot 8\end{array}$ & $\begin{array}{l}2 \frac{1}{2}-3 \frac{5}{16} \\
4 \frac{1}{2}-4 \frac{7}{8} \\
9 \frac{1}{4} \\
\text { About } 9\end{array}$ & $\begin{array}{c}1 \text { year } \\
2 \text { or } 3 \text { years } \\
\text {," }\end{array}$ & $\left\{\begin{array}{l}\text { Cleethorpes to Humberstone } \\
\text { Sands; shrimp šhove-net. }\end{array}\right.$ \\
\hline April 28 & $\begin{array}{l}4 \\
2\end{array}$ & $\begin{array}{c}5 \cdot 9-9 \cdot 1 \\
10 \cdot 8,15 \cdot 9\end{array}$ & $\begin{array}{c}2 \frac{5}{16}-3 \frac{5}{8} \\
4 \frac{1}{4}, 6 \frac{1}{4}\end{array}$ & 1 year & Cleethorpes Sands; shove-net. \\
\hline May 14 & 2 & $9 \cdot 5,12 \cdot 5$ & $3 \frac{3}{8}, 4 \frac{7}{8}$ & 1 year & Humberstone Sands; cart-trawl. \\
\hline
\end{tabular}




\begin{tabular}{|c|c|c|c|c|c|}
\hline $\begin{array}{l}\text { Date of } \\
\text { capture. }\end{array}$ & $\begin{array}{l}\text { No. of } \\
\text { specimens. }\end{array}$ & $\begin{array}{l}\text { Length in } \\
\text { centimetres. }\end{array}$ & $\begin{array}{l}\text { Length in } \\
\text { inches. }\end{array}$ & Probatle age. & Locality and mode of capture. \\
\hline May 20 & $\begin{array}{l}1 \\
2 \\
9 \\
8 \\
3 \\
3 \\
1 \\
1\end{array}$ & $\begin{array}{l}12 \cdot 7 \\
19 \cdot 0 \\
20 \cdot 3 \\
22 \cdot 9 \\
24 \cdot 1 \\
25 \cdot 4 \\
28 \cdot 0 \\
33 \cdot 0\end{array}$ & $\begin{array}{l}5 \\
7 \frac{1}{2} \\
8 \\
9 \\
9 \frac{1}{2} \\
10 \\
11 \\
13\end{array}$ & $\begin{array}{c}1 \text { year } \\
2 \text { years } \\
\text { " } \\
\text { " } \\
3 \text { years } \\
\text { ", }\end{array}$ & $\begin{array}{l}\text { Tetney, mouth of Humber; } \\
\text { shrimp trawler. }\end{array}$ \\
\hline May 24 & $\begin{array}{l}1 \\
1 \\
1 \\
2 \\
1 \\
2 \\
1\end{array}$ & $\begin{array}{l}16 \cdot 5 \\
19 \cdot 0 \\
20 \cdot 3 \\
22 \cdot 9 \\
24 \cdot 8 \\
25 \cdot 4 \\
30 \cdot 5\end{array}$ & $\begin{array}{c}6 \frac{1}{2} \\
7 \frac{1}{2} \\
8 \\
9 \\
9 \frac{3}{4} \\
10 \\
12\end{array}$ & $\begin{array}{c}1 \text { year } \\
\text {," } \\
2 \text { years } \\
", \\
", \\
3 \text { years }\end{array}$ & Humber; shrimp trawler. \\
\hline $\begin{array}{l}\text { June } 1 \\
\text { June } 3\end{array}$ & $\frac{1}{2}$ & $\begin{array}{c}7 \cdot 0 \\
8 \cdot 9,12 \cdot 0\end{array}$ & $\begin{array}{r}2 \frac{3}{4} \\
3 \frac{1}{2}, 7 \frac{1}{2}\end{array}$ & 1 year & Cleethorpes Sands; cart-trawl. \\
\hline
\end{tabular}

It will be seen from the table, that Mr. Holt has not obtained the young flounders of the year. The flounder spawns in the North Sea from February to the end of May, probably in March and April chiefly; there is thus no difference between the periods at Grimsby and at Plymouth, except that at Plymouth it begins and ends a few weeks earlier. The newly metamorphosed flounders appear at Mevagissey in the beginning of May or end of April, and are then only about $\frac{1}{2}$ inch long.

I should think that the shove-net is as well adapted to catch small flounders as small plaice, and there must be plenty of flounders of the year's brood somewhere in the neighbourhood of Grimsby in June and July. Probably the reason that they are absent from these collections is that they ascend the rivers, and are, therefore, not to be found at the mouth of the estuary with the plaice.

Pleuronectes limanda, the Dab.

\begin{tabular}{|c|c|c|c|c|c|}
\hline $\begin{array}{l}\text { Date of } \\
\text { collection. }\end{array}$ & $\begin{array}{c}\text { No. of } \\
\text { specimens. }\end{array}$ & $\begin{array}{l}\text { Length in } \\
\text { centimetres. }\end{array}$ & $\begin{array}{l}\text { Length in } \\
\text { inches. }\end{array}$ & Probable age. & $\begin{array}{l}\text { Locality and mode of } \\
\text { capture. }\end{array}$ \\
\hline Feb. 20 & $\begin{array}{l}1 \\
6 \\
5\end{array}$ & $\begin{array}{c}12 \cdot 1 \\
12 \cdot 3-15 \cdot 6 \\
16 \cdot 8-20 \cdot 3\end{array}$ & $\begin{array}{l}5 \frac{1}{4}-6 \frac{3}{4} \\
6 \frac{5}{8}-8\end{array}$ & $\begin{array}{c}1 \text { year, } q \text { immature } \\
2 \text { years, ripe } \\
,\end{array}$ & $\begin{array}{l}35 \text { miles E. of Flam- } \\
\text { borough Head, } \\
33 \text { fathoms. }\end{array}$ \\
\hline March 3 & $\begin{array}{r}3 \\
26 \\
6 \\
1\end{array}$ & $\begin{array}{c}16 \cdot 5-17 \cdot 1 \\
17 \cdot 8-20 \cdot 3 \\
20 \cdot 6-21 \cdot 3 \\
20 \cdot 4\end{array}$ & $\begin{array}{c}6 \frac{1}{2}-6 \frac{3}{4} \\
7-8 \\
8 \frac{1}{8}-8 \frac{3}{8} \\
10\end{array}$ & $\begin{array}{c}2 \text { years } \\
\text { ", } \\
3 \text { years } \\
,,\end{array}$ & $\begin{array}{l}45 \text { miles E.N.E. of } \\
\text { Spurn Light.vessel, } \\
33 \text { fathoms. }\end{array}$ \\
\hline
\end{tabular}

NEW SERIES.-VOL. II, NO. IV. 


\begin{tabular}{|c|c|c|c|c|c|}
\hline $\begin{array}{c}\text { Date of } \\
\text { collection. }\end{array}$ & $\begin{array}{c}\text { No. of } \\
\text { specimens. }\end{array}$ & $\begin{array}{l}\text { Length in } \\
\text { centimetres. }\end{array}$ & $\begin{array}{l}\text { Length in } \\
\text { inches. }\end{array}$ & Probable age. & Locality and mode of capture. \\
\hline March 30 & $\begin{array}{l}1 \\
2 \\
3 \\
1\end{array}$ & $\begin{array}{c}2 \cdot 0 \\
3 \cdot 2 \\
3 \cdot 8-5 \cdot 1 \\
8 \cdot 2\end{array}$ & $1_{3 \frac{1}{2}-\frac{1}{4}}^{\frac{3}{4}}-2$ & $\begin{array}{c}6 \text { weeks } \\
10 \text { months } \\
1 \text { year }\end{array}$ & $\begin{array}{l}\text { North Channel, Humber, } \\
1 \text { to } 2 \text { fathoms. }\end{array}$ \\
\hline April 2 & $\begin{array}{l}4 \\
4 \\
4\end{array}$ & $\begin{array}{l}13 \cdot 3-14 \cdot 6 \\
15 \cdot 9-17 \cdot 2 \\
20 \cdot 6-22 \cdot 9\end{array}$ & $\begin{array}{l}5 \frac{1}{4}-5 \frac{3}{4} \\
6 \frac{1}{4}-6 \frac{3}{4} \\
8 \frac{1}{5}-9\end{array}$ & $\begin{array}{l}2 \text { years } \\
\text { " } \\
3 \text { years }\end{array}$ & $\begin{array}{l}\text { S.W. edge of Dogger, } \\
12 \frac{1}{2} \text { to } 33 \text { fathoms. }\end{array}$ \\
\hline April 6 & $\begin{array}{r}2 \\
1 \\
11 \\
20 \\
15 \\
1\end{array}$ & $\begin{array}{c}7 \cdot 0-7 \cdot 6 \\
14 \cdot 0 \\
15 \cdot 3-17 \cdot 2 \\
17 \cdot 8-19 \cdot 7 \\
20 \cdot 3-22 \cdot 2 \\
24 \cdot 1\end{array}$ & $\begin{array}{c}2 \frac{3}{4}-3 \\
5 \frac{1}{2} \\
6-6 \frac{8}{4} \\
7-7 \frac{3}{4} \\
8-8 \frac{3}{4} \\
9 \frac{1}{2}\end{array}$ & $\begin{array}{c}1 \text { year } \\
2 \text { years } \\
2 \text { years } \\
\text { ", }\end{array}$ & $\begin{array}{l}\text { W. edge of Dogger, } \\
27 \text { to } 30 \text { fathoms. }\end{array}$ \\
\hline $\begin{array}{l}\text { April } 25 \\
\text { April } 28\end{array}$ & 3 & $\begin{array}{l}3 \cdot 3-4 \cdot 4 \\
4 \cdot 1-4 \cdot 7\end{array}$ & $\begin{array}{l}1 \frac{1}{4}-1 \frac{3}{4} \\
1 \frac{5}{8}-1 \frac{7}{8}\end{array}$ & 1 year & $\begin{array}{c}\text { Cleethorpes to Humber- } \\
\text { stone Sands; shrimp } \\
\text { shove-net. } \\
\text { Cleethorpes Sands; } \\
\text { shove-net. }\end{array}$ \\
\hline May 10 & $\begin{array}{l}5 \\
5\end{array}$ & $\begin{array}{l}4 \cdot 1-5 \cdot 0 \\
5 \cdot 2-8 \cdot 9\end{array}$ & $\begin{array}{l}1 \frac{5}{8}-2 \\
2 \frac{1}{16}-3 \frac{1}{5}\end{array}$ & ", & Ditto, by night. \\
\hline May 14 & 2 & $4 \cdot 8$ & $1 \frac{7}{8}$ & , & $\begin{array}{l}\text { Humberstone Sands; } \\
\text { cart-trawl. }\end{array}$ \\
\hline July 12 & $\begin{array}{l}7 \\
1\end{array}$ & $\begin{array}{c}5 \cdot 7-9 \cdot 5 \\
33 \cdot 0\end{array}$ & $2 \frac{1}{4}-2 \frac{3}{4}$ & $\begin{array}{c}1 \text { year } 3 \text { months } \\
4 \text { years }\end{array}$ & $\left\{\begin{array}{c}\text { Inner shoal water of } \\
\text { Great Fisher Bank, } 30 \\
\text { fathoms trawl amongst } \\
\text { Flustra foliacea. }\end{array}\right.$ \\
\hline
\end{tabular}

Mr. Holt tells me that the dab began to spawn at Grimsby in the middle of February, and continued till the end of May; March and April being the principal months. Taking this into consideration, I find that among all the specimens registered above only one could possibly be derived from the spawning of 1892, namely the specimen $\frac{3}{4}$ inch long, taken on March 30th. I do not think that a specimen, hatched towards the end of February, could reach a length of $1 \frac{1}{4}$ inches by the end of March, and have, therefore, attributed the specimens of that size to the spawning of the previous year. The young dabs from the same year's spawning were not taken in the shore-nets in June and July together with the plaice. I have estimated the probable age of the larger specimens in accordance with the considerations discussed in a former paper (this Journal, vol. ii, No. 2, p. 101). The examination of these specimens confirms the conclusions I formed from those collected at Plymouth.

There is only one specimen of the lemon sole (Pleuronectes microcephalus) in the collection; it is $7 \frac{1}{2}$ inches ( $19 \mathrm{~cm}$.) long, taken on the south-west edge of the Dogger Bank in $12 \frac{1}{2}$ to 33 fathoms on April 2 nd. This specimen may have been one year old, but was more 
probably two years. Three specimens of the long rough dab

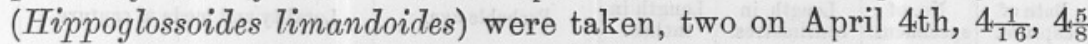
inches long $(10.3,11.8 \mathrm{~cm}$.) on the west edge of the Dogger, and one on July 12th, on the Great Fisher Bank, $5 \frac{1}{2}$ inches long (14 cm.). These three were doubtless year-old fish. The limits of the spawning period were not observed, but some fish of this species were found to be spawning in March.

Solea vulgaris, the Sole.

\begin{tabular}{|c|c|c|c|c|c|}
\hline $\begin{array}{l}\text { Date of } \\
\text { capture. }\end{array}$ & $\begin{array}{c}\text { No. of } \\
\text { specimens. }\end{array}$ & $\begin{array}{l}\text { Length in } \\
\text { centimetres. }\end{array}$ & $\begin{array}{l}\text { Length in } \\
\text { inches. }\end{array}$ & Probable age. & Locality and mode of capture. \\
\hline Feb. 9 & 3 & $27 \cdot 3-30 \cdot 2$ & $\left|10 \frac{3}{4}-11 \frac{7}{8}\right|$ & 3rd year & \multirow{7}{*}{$\begin{array}{l}\text { Grimsby Market, smallest } \\
\text { procurable, probably from } \\
\text { Silver Pits. }\end{array}$} \\
\hline & 2 & $30 \cdot 5-32 \cdot 0$ & $12-12 \frac{5}{8}$ & , & \\
\hline Feb. 10 & 8 & $22 \cdot 8-29 \cdot 8$ & $9-11 \frac{3}{4}$ & $"$ & \\
\hline Feb. 11 & $\begin{array}{l}4 \\
3\end{array}$ & $\begin{array}{l}25 \cdot 1-29 \cdot 2 \\
30 \cdot 5-31 \cdot 4\end{array}$ & $\begin{array}{l}9 \frac{7}{8}-11 \frac{1}{2} \\
12-12 \frac{3}{8}\end{array}$ & ”, & \\
\hline \multirow[t]{2}{*}{ Feb. 20} & 3 & $25 \cdot 4-26 \cdot 9$ & $10-10 \frac{5}{8}$ & ", & \\
\hline & 6 & $28 \cdot 3-29 \cdot 5$ & $11 \frac{1}{8}-11 \frac{5}{8}$ & ", & \\
\hline Feb. ? & 7 & $\begin{array}{l}31 \cdot 1-31 \cdot 7 \\
28 \cdot 6-31 \cdot 1\end{array}$ & $\left|\begin{array}{l}12 \frac{4}{4}-12 \frac{1}{2} \\
11_{4}^{1}-12 \frac{1}{4}\end{array}\right|$ & " & \\
\hline March 30 & 1 & $14 \cdot 6$ & $5 \frac{3}{4}$ & 8 to 10 months & \multirow{3}{*}{$\begin{array}{c}\text { Humber, North Channel, } \\
1 \text { to } 2 \text { fathoms. } \\
\text { Cleethorpes; shrimp shove- } \\
\text { net. }\end{array}$} \\
\hline \multirow{4}{*}{$\begin{array}{l}\text { April } 25 \\
\text { April } 28\end{array}$} & 4 & $6 \cdot 0-8 \cdot 6$ & $2 \frac{3}{8}-3 \frac{3}{8}$ & 9 to 12 months & \\
\hline & 1 & $8 \cdot 9$ & $3 \frac{1}{2}$ & " & \\
\hline & $\begin{array}{l}1 \\
4\end{array}$ & $\begin{array}{c}20 \cdot 3 \\
22 \cdot 8-25 \cdot 4\end{array}$ & $\stackrel{8}{9-10}$ & $\begin{array}{l}1 \text { year } \\
2 \text { years }\end{array}$ & \multirow{2}{*}{$\begin{array}{l}\text { Grimsby Market, smallest } \\
\text { procurable. }\end{array}$} \\
\hline & 2 & $27 \cdot 9$ & 11 & " & \\
\hline May 4 & 2 & $7 \cdot 6,9 \cdot 5$ & $3,3 \frac{3}{4}$ & 9 to 12 months & Cleethorpes Sands; shove- \\
\hline May 10 & 2 & $6 \cdot 5,7 \cdot 3$ & $2 \frac{1}{2}, 2 \frac{7}{8}$ & " & net. \\
\hline May 14 & 1 & $11 \cdot 8$ & $4 \frac{5}{8}$ & $"$ & $\begin{array}{c}\text { Humberstone Sands ; cart- } \\
\text { trawl. }\end{array}$ \\
\hline \multirow[t]{5}{*}{ May 16} & 9 & $22 \cdot 8-24 \cdot 1$ & $9-9 \frac{1}{2}$ & 2 years & \multirow{5}{*}{$\begin{array}{c}\text { Grimsby Market, from } \\
\text { Dutch coast, smallest pro- } \\
\text { curable; nearly all males. } \\
\text { Humber; shrimp trawler; } \\
\text { the whole catch sold, but } \\
\text { smaller fish may have been } \\
\text { eliminated at sea. }\end{array}$} \\
\hline & 29 & $25 \cdot 4-26 \cdot 6$ & $10-10 \frac{1}{2}$ & , & \\
\hline & 4 & $27 \cdot 9-29 \cdot 2$ & $11-11 \frac{1}{2}$ & " & \\
\hline & 2 & $20 \cdot 3,21 \cdot 6$ & $8,8 \frac{1}{2}$ & " & \\
\hline & $\begin{array}{l}4 \\
1\end{array}$ & $\begin{array}{c}22 \cdot 8-24 \cdot 1 \\
38 \cdot 1\end{array}$ & $9-9 \frac{1}{2}$ & 3 years & \\
\hline May 17 & 1 & $8 \cdot 4$ & $3 \frac{1}{4}$ & $9 \frac{1}{2}$ to $12 \frac{1}{2}$ months & $\begin{array}{c}\text { Cleethorpes Sands; shove- } \\
\text { net. }\end{array}$ \\
\hline \multirow[t]{3}{*}{ May 19} & $\begin{array}{r}2 \\
10\end{array}$ & $\begin{array}{l}17 \cdot 8-19 \cdot 0 \\
20 \cdot 3-21 \cdot 6\end{array}$ & $\begin{array}{l}7,7 \frac{1}{2} \\
8-8 \frac{1}{0}\end{array}$ & $\begin{array}{l}1 \text { year } \\
2 \text { vears }\end{array}$ & \multirow{12}{*}{$\begin{array}{c}\text { Humber; shrimp trawler; } \\
\text { whole catch as brought to } \\
\text { market. }\end{array}$} \\
\hline & 16 & $22 \cdot 8-24 \cdot 1$ & $9-9 \frac{2}{2}$ & , & \\
\hline & 2 & $25 \cdot 4-26 \cdot 6$ & $10-10 \frac{1}{2}$ & , & \\
\hline \multirow[t]{4}{*}{ May 27} & 3 & $20 \cdot 3$ & 8 & , & \\
\hline & 15 & $21 \cdot 6$ & $\begin{array}{l}8 \frac{1}{2} \\
9\end{array}$ & ” & \\
\hline & $\begin{array}{l}9 \\
6\end{array}$ & $\begin{array}{l}22 \cdot 8 \\
24 \cdot 1\end{array}$ & $\begin{array}{l}9 \\
9 \frac{1}{2}\end{array}$ & ", & \\
\hline & 1 & $25 \cdot 4$ & $10^{\circ}$ & , & \\
\hline \multirow[t]{5}{*}{ May 31} & 4 & $21 \cdot 6$ & $8 \frac{1}{2}$ & $"$ & \\
\hline & 3 & $22 \cdot 8$ & $9^{-}$ & $"$ & \\
\hline & 3 & $24 \cdot 1$ & $9 \frac{1}{2}$ & ”, & \\
\hline & 2 & $25 \cdot 4$ & 10 & " & \\
\hline & 1 & $26 \cdot 6$ & $10 \frac{1}{2}$ & $"$ & \\
\hline
\end{tabular}




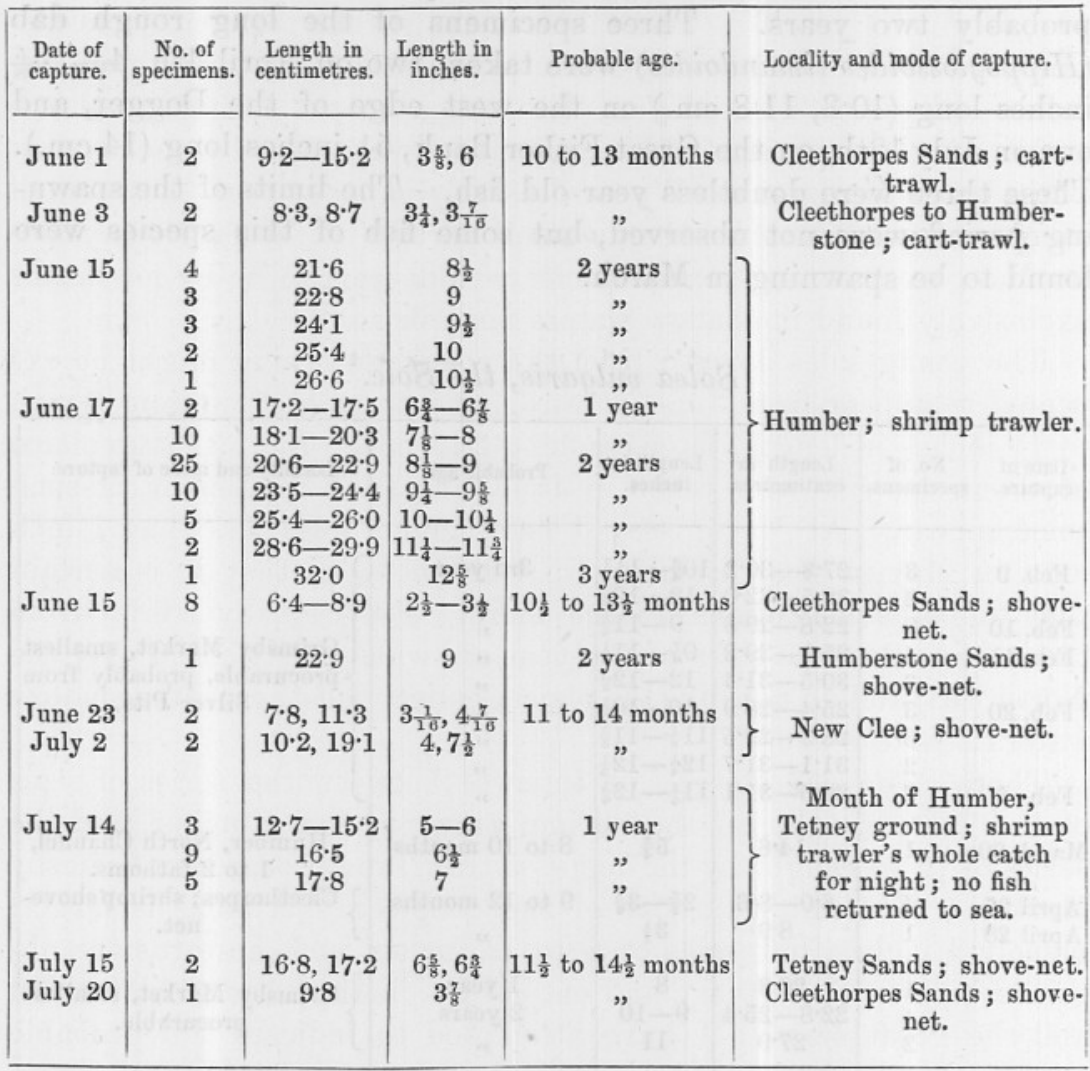

The most interesting feature of this collection is the absence of soles small enough to be referred to the spawning season of the same year. Mr. Holt finds that in the North Sea the spawning period of the sole coincides with that of the brill, but that it is not quite over till the beginning of August. Therefore, it begins at the end of April, goes on chiefly in May and June, and rare individuals are found spawning in July. The smallest specimens obtained are $2 \frac{3}{8}$ to $2 \frac{1}{2}$ inches, 6.0 to $6.4 \mathrm{~cm}$. long, and were taken in the shove-net on Cleethorpes sands in April, May, and June. These could not be less than nine or ten months old, and may have been more, so that some soles grow as slowly under natural conditions as some of the flounders which I have reared in captivity. These soles of the previous year's brood were taken chiefly in the shove-net or the cart-trawl quite close to the shore, very few appearing in the produce of the shrimp trawlers. The sole is somewhat larger than the flounder, and we may reasonably suppose that 8 inches is about the maximum length attained in one year's growth. 'The total number of specimens obtained which were less than 8 inches long is sixty- 
two, of which thirty-five were taken in the shrimp trawl at some distance from shore, and twenty-seven in the shove-net in less than one fathom of water. But the smallest taken in the shrimp trawl is 5 inches long, and some of the specimens between 5 and 8 inches may be in their third year. We can scarcely suppose that these small numbers represent more than a small portion of the previous year's produce, so that one-year-old soles would seem to be by no means exclusively found in shallow waters near shore.

The young soles derived from the year's spawning might be expected to appear from June onwards, and to be at first from $\frac{1}{2}$ inch to $1 \frac{1}{2}$ inches in length, later reaching 2 inches. But although plaice of about this size were taken in June, July, and September, no such soles appear. At Mevagissey I have found soles less than 1 inch long in May in small numbers in tide pools, so that it is certain they do occasionally come to the shore. Provisionally I infer from these facts that the soles of the year are widely distributed over the North Sea, and do not, like the plaice, collect together in the shallow waters near the shore.

There is no definite gap or interval between the series of sizes of the soles caught by the shrimp trawl in the Humber, and the series of those caught by the deep-sea trawl, and procured in Grimsby Market. The minimum size of the deep-sea specimens is larger, namely 8 inches, but soles of 8 to 12 inches and upwards are obtained both in the estuary and out at sea, both in the shrimp trawl and the great trawl. I have attempted to indicate the probable age of these specimens, taking 12 inches as about the maximum length, at two years of age; but, as I have before pointed out, the growth of fish is so variable in different individuals, that it is not possible to distinguish by size alone two-year-old specimens from those which are three years old or more.

Rhombus lævis, the Brill.

\begin{tabular}{|c|c|c|c|c|c|}
\hline $\begin{array}{l}\text { Date of } \\
\text { capture. }\end{array}$ & $\begin{array}{l}\text { No. of } \\
\text { specimens. }\end{array}$ & $\begin{array}{l}\text { Length in } \\
\text { centimetres. }\end{array}$ & $\begin{array}{l}\text { Length in } \\
\text { inches. }\end{array}$ & Probable age. & Locality and mode of capture. \\
\hline April 25 & 2 & $9 \cdot 1-9 \cdot 6$ & $3 \frac{5}{8}-3 \frac{3}{4}$ & $\begin{array}{l}9 \text { to } 11 \\
\text { months }\end{array}$ & $\begin{array}{l}\text { Cleethorpes to Humberstone } \\
\text { Sands; shrimp shove-net. }\end{array}$ \\
\hline April 28 & 1 & $10 \cdot 4$ & $4 \frac{1}{16}$ & , & $\begin{array}{l}\text { Cleethorpes Sands; shrimp shove- } \\
\text { net. }\end{array}$ \\
\hline May 4 & 2 & $7 \cdot 4-9 \cdot 6$ & $2 \frac{15}{16}-3$ & $\begin{array}{l}10 \text { to } 12 \\
\text { months }\end{array}$ & ",$\quad "$ \\
\hline May 14 & 2 & $9 \cdot 8-10 \cdot 8$ & $3 \frac{7}{8}-4 \frac{1}{4}$ & & Humberstone Sands; cart-trawl. \\
\hline June 15 & $\overline{2}$ & $8.9-10.4$ & $3 \frac{1}{2}-4 \frac{1}{8}$ & $\begin{array}{l}11 \text { to } 13 \\
\text { months }\end{array}$ & $\begin{array}{l}\text { Humberstone Sands ; shrimp } \\
\text { shove-net. }\end{array}$ \\
\hline July 20 & 1 & $13 \cdot 9$ & $5 \frac{1}{2}$ & , & Cleethorpes; shove-net. \\
\hline
\end{tabular}


Mr. Holt finds that the brill begins to spawn in the latter part of April, and that some ripe fish are found until the end of July, the majority of the fish shedding their eggs in May and the early part of June. It is clear, therefore, that the specimens recorded in the table are all about a year old. In a previous paper (Journ. Marine Biol. Assoc., vol. ii, No. 2) I recorded the growth of young brill reared by me in captivity in 1890-91; some of them reached 2.8 to 3.9 inches in length in six months, others 3.3 to 3.7 inches in twelve months. It is interesting to find that the specimens collected by Mr. Holt from the sea were no larger at the end of their first year than those reared in the Plymouth aquarium. At the same time these year-old brill were taken only in small numbers in the shrimp-nets in the Humber, and cannot be considered as fully representing the young fish derived from the spawning of the previous year. Probably the year-old fish are widely distributed from the shore to deep water, and the average and the maximum sizes for fishes at that age are probably greater than those of the above specimens. The young brill of the year are pelagic in May and June, and could not be taken on the bottom till August and September and following months

Rhombus maximus, the Turbot.

\begin{tabular}{|c|c|c|c|c|c|}
\hline $\begin{array}{l}\text { Date of } \\
\text { capture. }\end{array}$ & $\begin{array}{l}\text { No. of } \\
\text { specimens. }\end{array}$ & $\begin{array}{l}\text { Length of } \\
\text { centimetres. }\end{array}$ & $\begin{array}{l}\text { Length in } \\
\text { inches. }\end{array}$ & Probable age. & Locality and mode of capture. \\
\hline April 25 & 1 & $7 \cdot 9$ & $3 \frac{1}{8}$ & $\begin{array}{l}8 \text { to } 11 \\
\text { months }\end{array}$ & $\begin{array}{l}\text { Cleethorpes to Humberstone } \\
\text { Sands: shrimp shove-net. }\end{array}$ \\
\hline May 16 & 1 & $6 \cdot 8$ & $2 \frac{11}{16}$ & $\begin{array}{l}9 \text { to } 12 \\
\text { months }\end{array}$ & Cleethorpes; seine. \\
\hline May 16 & 2 & $7 \cdot 3,8 \cdot 5$ & $2 \frac{7}{8}, 3 \frac{3}{8}$ & & Humberstone Sands; cart-trawl. \\
\hline June 3 & 140 & $28 \cdot 0-38 \cdot 1$ & $11-15$ & 2 years & $\begin{array}{l}\text { Grimsby Market; trawler from } \\
\text { opposite coast; the whole catch } \\
\text { of this species. }\end{array}$ \\
\hline $\begin{array}{r}\text { June } 15 \\
\text { Take }\end{array}$ & en in surfa & cee-net: & $4 \frac{1}{8}$ & $\begin{array}{l}10 \text { to } 13 \\
\text { months }\end{array}$ & $\begin{array}{l}\text { Humberstone Sands; shrimp } \\
\text { shove-net. }\end{array}$ \\
\hline July 1 & 12 & & $\frac{3}{2} \frac{3}{16} \frac{5}{8}$ & A few weeks & $\left\{\begin{array}{l}22 \text { miles N.N.E. of Horn Light } \\
\text { Vessel. }\end{array}\right.$ \\
\hline July 12 & 1 & $\cdot 7$ & $\frac{1}{4}$ & ", & $\begin{array}{l}\text { Inner shoal of Great Fisher Bank; } \\
\text { about } 220 \text { miles N.E. by E. of } \\
\text { Spurn Light Vessel. }\end{array}$ \\
\hline July 28 & 22 & $\cdot 7-1 \cdot 3$ & $\frac{1}{4}-\frac{1}{2}$ & ", & $\begin{array}{l}150 \text { miles E. by N. of Spurn } \\
\text { Light Vessel. }\end{array}$ \\
\hline Aug. 10 & 6 & $\cdot 6-1 \cdot 6$ & $\frac{1}{4}-\frac{5}{8}$ & ," & $\begin{array}{l}\text { Off the N.W. corner of the } \\
\text { Dogger. }\end{array}$ \\
\hline
\end{tabular}

The spawning of the turbot in the North Sea, according to $\mathrm{Mr}$. Holt, is general in June and July, but occasional ripe fish occur as early as the end of March and as late as the beginning of September. 
In the above estimates of ages I have included, therefore, four spawning months-May, June, July, and August-leaving out April, when probably few turbot spawn. Those taken in shore waters in the shrimp-nets, like the young brill in the previous table, are undoubtedly from the spawning of the previous year, and probably represent only the most backward specimens of that year's brood. I have at present no evidence as to the average or the maximum length of year-old specimens; but as the maximum length of the turbot, according to Dr. Fulton, is 28 inches, I should think that most of those obtained in Grimsby Market on June 3rd, 11 to 15 inches long, were two years old, and some may have been three years.

Some observations on the growth of turbot in captivity were made many years ago in France, and are published in the Bulletin de la Société Impériale Zoologique d'Acclimatation for 16th June, 1865. At the aquarium of Concarneau young turbot hatched in June, 1864, had a length of 5 to $6 \mathrm{~cm}$., 2 to $2 \frac{3}{8}$ inches, on April 16th, 1865, and a mean weight of 4 grammes. Others, a little older, hatched in April, 1864, had on the same date a length of 14 to $19 \mathrm{~cm}$., $5 \frac{1}{2}$ to $7 \frac{1}{2}$ inches, and weighed 52 to 126 grammes. Others about two years old measured 20 to $28 \mathrm{~cm}$., $7 \frac{7}{8}$ to 11 inches, and weighed 200 to 380 grammes. All these specimens had been taken by the seine on sandy shores, and how far the ages given are accurate I am unable to say. But the sizes given agree closely with my own conclusions. The authors call particular attention to the inequality in the rate of growth, and give the same explanation as I have given for my captive flounders, namely, that the most greedy and boldest individuals seize all the food.

Gadus morrhua, the Cod.

\begin{tabular}{|c|c|c|c|c|c|}
\hline $\begin{array}{l}\text { Date of } \\
\text { capture. }\end{array}$ & $\begin{array}{c}\text { No. of } \\
\text { specimens. }\end{array}$ & $\begin{array}{l}\text { Length in } \\
\text { centimetres. }\end{array}$ & $\begin{array}{l}\text { Length in } \\
\text { inches. }\end{array}$ & Probable age. & Locality and mode of capture. \\
\hline July 12 & Many & $4 \cdot 7-12 \cdot 7$ & $1 \frac{3}{4}-5$ & 3 to 6 months & $\begin{array}{c}\text { Inner shoal-water of Great Fisher } \\
\text { Bauk, } 30 \text { fathoms, trawl, among } \\
\text { Flustra foliacea. }\end{array}$ \\
\hline Aug. 14 & 2 & $5 \cdot 0,6 \cdot 3$ & $2,2 \frac{1}{2}$ & 4 or 5 montlis & $\begin{array}{l}54 \text { miles E. of Spurn Light } \\
\text { Vessel; trawl, } 20 \text { fathoms. }\end{array}$ \\
\hline $\begin{array}{l}\text { Sept. } 7 \\
\text { Sept. } 9\end{array}$ & $\begin{array}{r}1 \\
13 \\
3\end{array}$ & $\begin{array}{l}7 \cdot 3 \\
6 \cdot 0-7 \cdot 3 \\
8 \cdot 0-9 \cdot 8\end{array}$ & $\begin{array}{l}2 \frac{7}{8} \\
2 \frac{3}{8}-2 \frac{7}{8} \\
3 \frac{1}{8}-3 \frac{7}{8}\end{array}$ & 5 or 6 months & \}Shrimp trawl, off Humberstone. \\
\hline
\end{tabular}

The cod spawns chiefly from the end of January to the end of April, and it is evident that these specimens belong to the year's produce. They seem to be widely distributed, having been taken 
both on the Fisher Bank in the middle of the North Sea, and in the estuary of the Humber.

Gadus merlangus, the Whiting.

\begin{tabular}{|c|c|c|c|c|c|}
\hline $\begin{array}{l}\text { Date of } \\
\text { capture. }\end{array}$ & $\begin{array}{c}\text { No. of } \\
\text { specimens. }\end{array}$ & $\begin{array}{l}\text { Length in } \\
\text { centimetres. }\end{array}$ & $\begin{array}{l}\text { Length in } \\
\text { inches. }\end{array}$ & Probable age. & Locality and mode of capture. \\
\hline Jan. 29 & $\begin{array}{r}118 \\
11\end{array}$ & $\begin{array}{c}10 \cdot 2-14 \cdot 9 \\
15 \cdot 2-19\end{array}$ & $\begin{array}{l}4-5 \frac{7}{8} \\
6-7 !\end{array}$ & $\begin{array}{l}9 \text { months } \\
11 \text { months }\end{array}$ & $\begin{array}{l}\text { Sprat stake-nets at Humber- } \\
\text { stone Sands. }\end{array}$ \\
\hline Feb. 20 & 2 & $17 \cdot 1-21$ & $6 \frac{3}{4}-8 \frac{1}{4}$ & $\begin{array}{l}11 \text { months } \\
\text { and } 2 \text { years }\end{array}$ & $\begin{array}{l}35 \text { miles E. of Flamborough Head; } \\
33 \text { fathoms. }\end{array}$ \\
\hline Mar. 3 & 1 & $14: 6$ & $5 \frac{3}{4}$ & 1 year & $\begin{array}{l}45 \text { miles E.N.E. of Spurn Light } \\
\text { Vessel; } 33 \text { fathoms. }\end{array}$ \\
\hline Mar. 30 & 5 & $12 \cdot 1-15 \cdot 2$ & $4 \frac{3}{4}-6$ & " & $\begin{array}{l}\text { North Channel, Humber; } 1 \text { to } 2 \\
\text { fathoms. }\end{array}$ \\
\hline April 2 & 2 & $22 \cdot 9-25 \cdot 4$ & $9-10$ & 2 years & $\begin{array}{l}\text { S.W. corner of Dogger ; } 20 \text { to } 26 \\
\text { fathoms. }\end{array}$ \\
\hline April 2 & Number & $16 \cdot 5$ & $\begin{array}{c}6 \frac{1}{2} \\
\text { upwards }\end{array}$ & $\begin{array}{c}1 \text { and } 2 \\
\text { years }\end{array}$ & $\begin{array}{l}\text { S.W. edge of Dogger; } 12 \frac{1}{2} \text { to } 33 \\
\text { fathoms. }\end{array}$ \\
\hline April 2 & , & $20 \cdot 3$ & $\begin{array}{c}8 \\
\text { upwards }\end{array}$ & 2 years & $\begin{array}{l}\text { W. edge of Dogger; } 20 \text { to } 33 \\
\text { fathoms. }\end{array}$ \\
\hline May 10 & 2 & $10 \cdot 2-14$ & $4,5 \frac{1}{2}$ & 11 months & $\begin{array}{l}\text { Cleethorpe Sands; shrimp shove- } \\
\text { net. }\end{array}$ \\
\hline Aug. 8 & 1 & $8 \cdot 3$ & $3 \frac{1}{4}$ & 4 months & $\begin{array}{l}54 \text { miles E. of Spurn Light } \\
\text { Vessel ; } 20 \text { fathoms. }\end{array}$ \\
\hline Aug. 28 & 7 & $7 \cdot 6-9 \cdot 2$ & $3-3 \frac{5}{8}$ & " & $\begin{array}{l}61 \text { miles E. by S. of Spurn Light } \\
\text { Vessel; } 16 \text { to } 20 \text { fathoms. }\end{array}$ \\
\hline $\begin{array}{l}\text { Sept. } 7 \\
\text { Sept. } 9\end{array}$ & $\begin{array}{r}44 \\
254\end{array}$ & $\begin{array}{l}7 \cdot 3-11 \cdot 1 \\
6 \cdot 7-12 \cdot 6\end{array}$ & $\begin{array}{l}2 \frac{7}{8}-4 \frac{3}{8} \\
2 \frac{5}{8}-4 \cdot 1 \frac{15}{10}\end{array}$ & 3 to 6 months & s $\}$ Off Humberstone; shrimp \\
\hline Sept. 10 & 1 & 9.5 & $3 \frac{3}{4}$ & $"$ & $\begin{array}{c}\text { Cleethorpes to Humberstone; } \\
\text { shove-net. }\end{array}$ \\
\hline
\end{tabular}

Mr. Holt finds that the whiting spawns in the North Sea from the beginning of March to the early part of June, chiefly in April. It is evident, therefore, that whiting taken on January 29th could not be less than eight months old. The specimens taken on this date are from 4 to $7 \frac{1}{2}$ inches long. The smaller, 4 to $5 \frac{7}{9}$ inches, might, I think, easily have reached that length if spawned the preceding April. The others, 6 to $7 \frac{1}{2}$ inches long, are more doubtful ; the adult whiting does not exceed 16 inches in length, and some flounders, which are of the same size when full grown, reach $7 \frac{1}{2}$ inches in a year; I have, therefore, estimated the age of these whiting at eleven months. I do not think, however, that a whiting could reach $8 \frac{1}{4}$ inches in less than one year, and have put down the specimen of this size of February 20th as two years old. The whiting of the year appear, like the plaice, in large numbers in inshore waters, but later in the year; this is shown by the abundance of young specimens taken in the Humber at the beginning of September. They are not, however, entirely restricted to littoral zones, some having been taken in August in the middle of the North Sea. 
Gadus æglefinus, the Haddock.

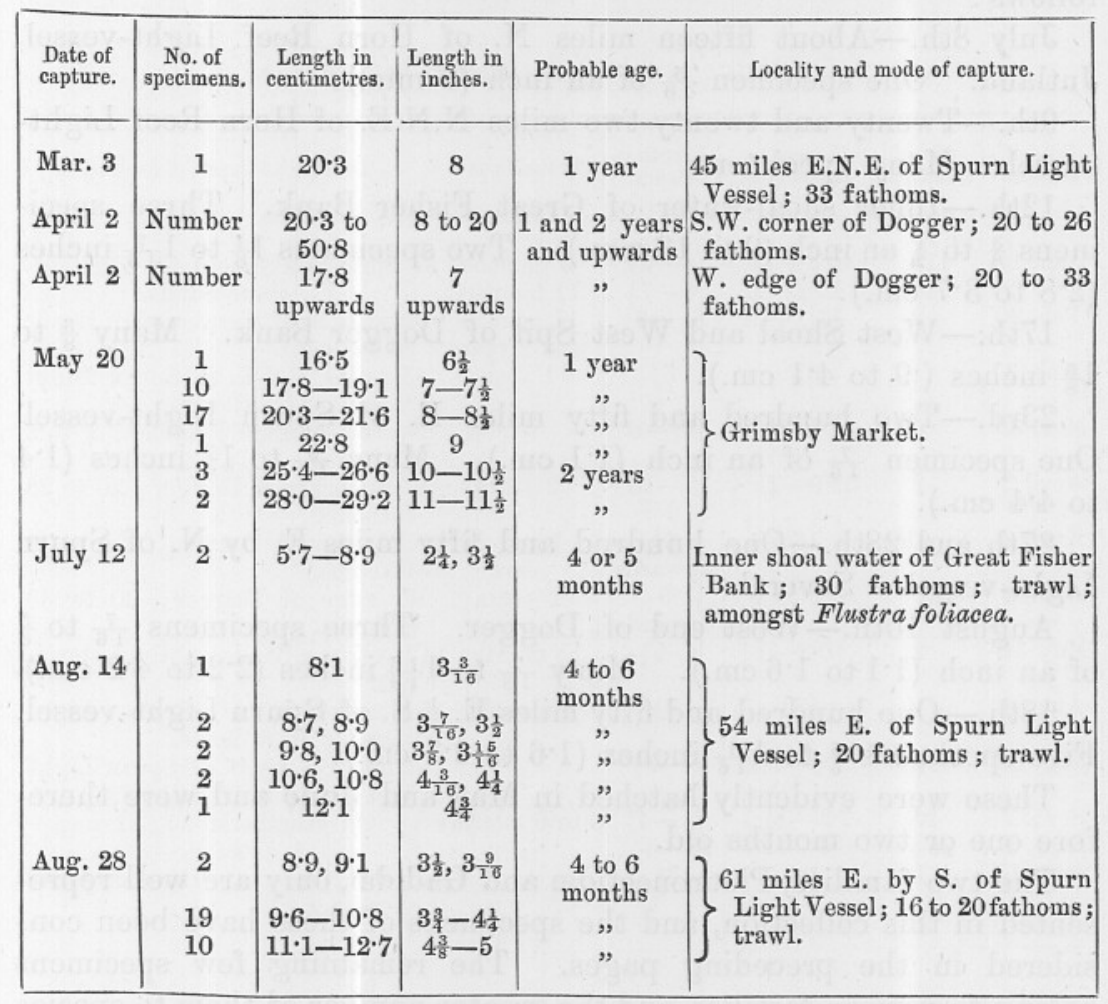

The haddock spawns in February, March, and April, especially in March. Young specimens derived from the year's spawning were taken on three occasions, once in July, twice in August. The number taken was not very great, and all were taken in the open sea, on the trawling grounds far from shore; none were taken in the shrimp-net or shrimp-trawls in the Humber.

These results agree with those of Dr. Fulton, published in the eighth Annual Report of the Scottish Fishery Board. I have for convenience fixed the limit between specimens one year old and two years old at 10 inches. It is evident from the entry for May 20th that a large number of year-old immature haddocks are brought to market by the trawlers.

Of Gadus luscus, the pout, only one specimen was obtained; it was $3 \frac{5}{8}$ inches, $9 \cdot 2 \mathrm{~cm}$. long, and was taken in the sprat stake-net at Humberstone on January 29th. This specimen was probably hatched in the previous May or June, and was, therefore, about seven months old.

A number of young Motella, apparently $M$. tricirrata, were taken 
in the surface tow-nets at various positions in the North Sea as follows :

July 8th.-About fifteen miles N. of Horn Reef Light-vessel, Jutland. One specimen $\frac{5}{16}$ of an inch $(8 \mathrm{~mm}$.$) .$

9th.-Twenty and twenty-two miles N.N.E. of Horn Reef Lightvessel. Many specimens.

12th.-Inner shoal-water of Great Fisher Bank. Three specimens $\frac{3}{8}$ to $\frac{1}{2}$ an inch (9 to $13 \mathrm{~mm}$.). Two specimens $1 \frac{1}{8}$ to $1 \frac{7}{16}$ inches $(2.8$ to 3.7 cm. $)$.

17th.-West Shoal and West Spit of Dogger Bank. Many $\frac{3}{8}$ to $1 \frac{5}{8}$ inches $(\cdot 9$ to $4 \cdot 1 \mathrm{~cm}$.).

23rd.-Two hundred and fifty miles E. of Spurn Light-vessel. One specimen $\frac{7}{16}$ of an inch $\left(1 \cdot 1 \mathrm{~cm}\right.$.). Many $\frac{9}{16}$ to $1 \frac{3}{4}$ inches $(1.4$ to $4 \cdot 4 \mathrm{~cm}$.).

27 th and 28th.-One hundred and fifty miles E. by N. of Spurn Light-vessel. Several.

August 10th.-West end of Dogger. Three specimens $\frac{7}{16}$ to $\frac{5}{8}$ of an inch $\left(1 \cdot 1\right.$ to $1 \cdot 6 \mathrm{~cm}$.). Many $\frac{7}{18}$ to $1 \frac{13}{16}$ inches $(2 \cdot 2$ to $4 \cdot 2 \mathrm{~cm}$.).

18th.-One hundred and fifty miles E. $\frac{1}{2}$ S. of Spurn Light-vessel. Five specimens $\frac{5}{6}$ to $1 \frac{1}{16}$ inches $(1 \cdot 6$ to $2 \cdot 7 \mathrm{~cm}$.).

These were evidently hatched in May and June and were therefore one or two months old.

The two families, Pleuronectidæ and Gadidæ, only are well represented in this collection, and the specimens of these have been considered in the preceding pages. The remaining few specimens belong to various families, and the greater number of them to species of no value in the market.

Clupea harengus (Herring).-Two specimens $6 \frac{3}{4}$ and $7 \frac{3}{8}$ inches $(17 \cdot 2,19.7$ cm.), taken in sprat stake-net, Humberstone sands, January 29th. These were probably a year and four or five months old, assuming that they were derived from spawn shed in autumn, in August or September.

Clupea sprattus (Sprats).-Three $3 \frac{3}{4}$ inches $\left(9 \cdot 5 \mathrm{~cm}\right.$.), five $4 \frac{1}{4}$ inches $(10.8 \mathrm{~cm}$.$) , one 5 \frac{1}{4}$ inches $(12.3 \mathrm{~cm}$.$) , in the same net, same date.$

These were all adult or nearly so; the smallest would probably be two years old, the larger three years in the following March or April.

Osmerus eperlanus (Smelt).

April 25th.-Five $3 \frac{1}{2}$ to $3 \frac{7}{8}$ inches $(8.9$ to $9 \cdot 8 \mathrm{~cm}$.), Cleethorpes, shove-net.

25th.-One $6 \frac{5}{8}$ inches ( $16.0 \mathrm{~cm}$.), Cleethorpes, shove-net.

July 3rd.-Three $4 \frac{1}{2}$ to $4 \frac{3}{4}$ inches $(11 \cdot 5$ to $12 \cdot 1)$, Cleethorpes, cart-trawl.

The smelt spawns about April, and the smaller specimens taken 
at Cleethorpes were doubtless a year old, the specimen $6 \frac{5}{8}$ inches long two years. The three taken in July were about fifteen months old.

Anguilla vulgaris (Eel).-A number of young eels, about $2 \frac{1}{2}$ to $2 \frac{3}{4}$ inches long $(6 \cdot 3$ to $7 \cdot 0 \mathrm{~cm}$.), were taken on March 30 th in the Humber, North Channel, at a depth of one to two fathoms by the shrimp trawl. Such young eels, very transparent at this size, are found everywhere in spring, and seem to be derived from spawn shed the previous autumn, so that they are three or four months old.

Scomber scomber (the Mackerel).-A few specimens were obtained by $\mathrm{Mr}$. Holt in the tow-net.

July 9th.-Twenty-two miles N.N.E. of Horn Reef Light-vessel. Twelve specimens from $6 \cdot 0$ to $9 \cdot 0 \mathrm{~mm}$. (about $\frac{1}{4}$ of an inch).

27th and 28th.-One hundred and fifty miles E. by N. of Spurn Light-vessel. Three from 13.5 to $19.25 \mathrm{~mm}$. ( $\frac{1}{2}$ to $\frac{3}{4}$ of an inch).

These are the first young mackerel of the year's brood that have yet been obtained and recognised. The largest specimens already showed the specific characters, the smaller were larval. They will be described by Mr. Holt. The mackerel spawns in June and July, and the largest of these specimens were probably one to two months old.

\section{Agonus cataphractus.}

April 25th.-One $2 \frac{1}{8}$ inches $(5.4 \mathrm{~cm}$.), Cleethorpes, shove-net.

28th.-Three $2 \frac{1}{8}$ to $2 \frac{5}{8}$ inches $(5 \cdot 4$ to $6.6 \mathrm{~cm}$.), Cleethorpes, shove-net.

May 10th.-Twenty $2 \frac{1}{4}$ to 3 inches $(5.7$ to $7.6 \mathrm{~cm}$.), two 5 to $5 \frac{1}{2}$ inches $(12.7$ to $14 \mathrm{~cm}$.), Cleethorpes, shove-net.

This species has adhesive ova, which at Plymouth are deposited in February and March, at Grimsby probably a little later. The specimens up to 3 inches I consider to be just over a year old, at 5 inches they may be two or three years, as the maximum length is only $6 \frac{1}{2}$ inches.

Cottus bubalis.

May 10th.- Seven $2 \frac{1}{2}$ to $2 \frac{3}{4}$ inches $(6 \cdot 3$ to $7 \cdot 0 \mathrm{~cm}$.), two 3 inches $(7 \cdot 6 \mathrm{~cm}$.$) , one 4 \frac{3}{4}$ inches $(12 \cdot 1 \mathrm{~cm}$.$) , Cleethorpes, shove-net.$

This species spawns early in the year, from January to March or April. The specimens up to 3 inches were probably in their second year, the last specimen, $4 \frac{3}{4}$ inches, two years old at least.

Callionymus lyra (the Dragonet).-Twenty-nine specimens of this species, ranging from $1 \frac{3}{4}$ to $2 \frac{5}{9}$ inches in length, were taken in the shove-nets on April 25th and 28th. The adults spawn between February and May, and these small specimens were doubtless just a year old.

Gobius minutus.-This species lives on sandy shores, and is 
always taken in shrimp-nets. At Cleethorpes, in the shove-net, April 25th, 261 were taken, ranging from $1 \frac{1}{8}$ to $3 \frac{7}{8}$ inches in length. These were of all ages, one year upwards, the adult not exceeding $3 \frac{1}{2}$ inches. It spawns in spring.

Syngnathus acus (Common Pipe-fish).

April 25th.-Two $3 \frac{1}{2}$ to $4 \frac{3}{4}$ inches (8.9 to $12.2 \mathrm{~cm}$.), at Cleethorpes, shove-net.

June 3rd.-Twenty-four $3 \frac{1}{4}$ to $4 \frac{7}{8}$ inches $(8 \cdot 3$ to $12 \cdot 4 \mathrm{~cm}$.), at Cleethorpes, cart-trawl.

When adult this species is 12 to 16 inches long, so that these specimens are presumably not more than a year old; but they are nearly all breeding, the males carrying ova, and many of the females full. These young specimens differ from the large adults in several characters, and appear at first sight to belong to a distant species. The subject is discussed in Günther's Brit. Mus. Catalogue, vol. viii, p. 159. 